\title{
Omega-3 fatty acids reduce the development of preneoplasic lesions ${ }^{1}$
}

\author{
Ácidos graxos ômega-3 reduzem o \\ desenvolvimento de lesões pré-neoplásicas
}

Viviana Teixeira HENRIQUES²

Cristina Maria Ganns Chaves DIAS 3

Sylvia do Carmo Castro FRANCESCHINI ${ }^{2}$

Céphora Maria SABARENSE ${ }^{2}$

Neuza Maria Brunoro COSTA ${ }^{2}$

Jacqueline Isaura Alvarez LEITE4

Maria do Carmo Gouveia PELUZIO²

A B S T R A C T

\section{Objective}

The purpose of this study was to evaluate the anticancer potential of dietary omega-3 supplementation to reduce induced intestinal preneoplastic lesions in Wistar rats.

\section{Methods}

A total of 58 11-week-old male Wistar rats (Rattus norvergicus, albinus variety, Rodentia) were distributed into two groups: a control group $(n=25)$ and an omega-3-treated group $(n=28)$. Aberrant crypt foci were induced by 1,2-dimethylhydrazine. Tissue incorporation of the supplemented omega-3 fatty acids was evaluated by determining the fatty acid profiles of intra-abdominal fat and the liver with gas chromatography.

\section{Results}

The omega-3 group presented lower weight and lower food intake $(p<0.05)$ than the control group. The number of aberrant crypt foci decreased $55.34 \%$ in response to omega-3 supplementation. Foci with more than three crypts decreased $57.14 \%$ between weeks 13 and 28 . There was no statistical difference for the docosahexaenoic acid content in the liver of the omega-3 group between week 6 and weeks 13 and 28.

\footnotetext{
$\mathbf{1}$ This paper is part of Ms dissertation of V.T. HENRIQUES, title "Effect of Omega-3 dietary supplementation in colorectal carcinogenesis induced by dimenthylhydrazine in Wistar rats". Nutrition Science Program. Universidade Federal de Viçosa; 2004.

2 Universidade Federal de Viçosa, Centro de Ciências Biológicas e da Saúde, Departamento de Nutrição e Saúde. Av. P.H. Rolfs, s/n., 36571-000, Viçosa, MG, Brasil. Correspondência para/Correspondence to: M.C.G. PELUZIO. E-mail: <mpeluzio@ufv.br>.

3 Universidade Federal do Tocantins, Curso de Medicina. Palmas, TO, Brasil.

${ }^{4}$ Universidade Federal de Minas Gerais, Instituto de Ciências Biológicas, Departamento de Bioquímica e Imunologia. Belo Horizonte, MG, Brasil.
} 
238 | V.T. HENRIQUES et al.

\section{Conclusion}

These results suggest that omega-3 may slow the progress of colorectal carcinogenesis.

Indexing terms: Fatty acids. Precancerous. Dietary supplements.

\section{R E S U M O}

\section{Objetivo}

O objetivo do estudo foi avaliar o potencial anticarcinogênico da suplementação com ômega-3 em reduzir lesões pré-neoplásicas induzidas em intestino de ratos Wistar.

\section{Métodos}

Ratos Wistar machos, com 11 semanas de idade (Rattus norvergicus), foram subdivididos em dois grupos: grupo controle $(n=25)$ e grupo ômega-3 $(n=28)$. Os focus de criptas aberrantes foram induzidos pela 1,2 dimetilhidrazina. A incorporação dos ácidos graxos ômega-3 suplementados foi avaliada pela identificação do perfil de ácidos graxos da gordura intra-abdominal e do fígado por cromatografia gasosa.

\section{Resultados}

O grupo ômega-3 apresentou menor consumo da dieta e menor ganho de peso $(p<0,05)$ do que o grupo controle. O número de focus de criptas aberrantes foi reduzido em 55,34\% como conseqüência da suplementação dietética com ômega-3. Os focus com três ou mais do que três criptas diminuíram 57, 14\% entre a $13^{a}$ a $28^{a}$ semanas. Não foi verificada diferença estatística para o conteúdo de ácido docosahexaenóico.

\section{Conclusão}

O resultado sugere que o ômega-3 pode reduzir a evolução da carcinogênese colorretal.

Termos de indexação: Ácidos graxos. Condições pré-cancerosas. Suplementos dietéticos.

\section{N TRO D U C T IO N}

There is a great research interest in polyunsaturated fatty acids (PUFA), particularly omega-3. This fatty acid is currently known to play a role in the prevention and treatment of cardiovascular diseases, hypertension, arthritis, autoimmune diseases, cancer and inflammatory diseases ${ }^{1-4}$. Dietary omega-3 intake from fish meat or fish oil may reduce intestinal disorders and be an effective adjuvant in colon cancer therapy ${ }^{5}$.

Epidemiological studies have found a low incidence of colon cancer in Finland and in areas of the Mediterranean where the consumption of fats is high and the main sources of the omega-3 family are fish and PUFA-rich fish oils ${ }^{6,7}$.

Likewise, the prevalence of colon cancer is low among the Inuit populations of Greenland. Their consumption of long-chain omega-3 PUFAs (EPA and DHA) is higher than $10 \mathrm{~g} /$ day, whereas the 'Western diet' averages 1-2g/day8.
Animal studies have also provided evidence that omega-3 intake reduced the risk of colorectal cancer $^{9,10}$. This reduction is associated with DHA intake since this fatty acid prevails in fish oil. The mechanism of action is probably associated with the ability of DHA to regulate $\mathrm{COX}-2$ production, which decreases the expression of the antiapoptotic proteins $\mathrm{BCl}-2$, accelerating apoptosis. Cellular death is essential for the regulation of epithelial cell numbers and prevention of mutant cell proliferation. Other possibilities include the ability of DHA to modulate pro-inflammatory gene expression, sensitize colon adenocarcinoma to receptor-mediated apoptosis and reduce the $\mathrm{S}$ phase of the cell cycle.

The potential of omega-3 to treat colorectal cancer was assessed by determining the anticancer ability of omega-3 supplementation to reduce intestinal preneoplastic lesions in Wistar rats. 


\section{METHODS}

Fifty-eight 11-week-old male Wistar rats (Rattus norvergicus, variety albinus, Rodentia) were distributed into two groups: a control group $(n=25)$ and an omega-3-treated group ( $\mathrm{n}=28$ ). All animals had similar body weight at the beginning of the study. The animals were housed at the Animal Breeding Center of the Center of Biology and Health, Universidade Federal de Viçosa (MG), Brazil. The animals were in a $23^{\circ} \mathrm{C}$ (standard deviation $=2^{\circ} \mathrm{C}$ ) environment with $12 \mathrm{~h}$ dark/light cycle, and had free access to food and water for 30 weeks.

Four subcutaneous injections of 1,2dimethylhydrazine-dihydrochloride $(\mathrm{DMH}$, $40 \mathrm{mg} / \mathrm{kg}$ of body weight, SIGMA ${ }^{\circledR}$, USA) twice per week at fixed intervals were used to induce preneoplastic lesions. DMH was diluted in $\mathrm{NaCl}$ $0.9 \%$ containing $15 \%$ EDTA immediately before use and the final pH was adjusted to 6.5 , according to the method used by Rodrigues et al. ${ }^{11}$.

The experimental diets were prepared as recommended by the American Institute of Nutrition ${ }^{12}$ following the AIN-93M protocol. Dietary supplementation was done by adding $10 \mathrm{~g}$ of omega-3 from fish oil capsules per $100 \mathrm{~g}$ of diet. The PUFA profile of the standard diet of the control group was $40.48 \%$ of linoleic acid and $0.49 \%$ of alpha-linolenic acid. The experimental diet had $12.08 \%$ of linoleic acid, $1.7 \%$ of alpha-linolenic acid, $20.56 \%$ of EPA and $15.27 \%$ of DHA.

Food intake and animal weights were monitored weekly. The food intake efficiency rate (FER) was estimated by the formula:

$\mathrm{FER}=\frac{\mathrm{FW}-\mathrm{IW} ; \text { where: FW: final weight; IW: initial }}{\text { Intake }}$ weight; Intake: average dietary intake.

Tissue samples were collected in weeks 6 , 13 and 28 after administration of the carcinogen. The large bowel was removed from the cecum down to the anus, rinsed in saline, opened longitudinally, placed in paraffin-coated wood plates with the mucosa facing up and fixed flat for one hour in $10 \%$ formaldehyde. Next, the sample was measured and divided into three equal fragments referred to as proximal, medium and distal in relation to the cecum, stained with $1 \%$ methylene blue for 2 minutes and rinsed with a phosphate buffer (PBS).

The surface of the intestinal mucosa was histologically examined using a light microscope, 100x magnification, for ACF and aberrant crypt identification, according to the technique used by Bird $^{13}$. The ACF in the entire mucosal surface of the large bowel, from the colon to the rectum, were counted blindly by two independent and welltrained observers. ACF categorization (crypt multiplicity) was determined by counting the foci containing three or fewer aberrant crypts $(\mathrm{ACF}<3)$ and foci with more than three aberrant crypts $(A C F>3)$.

After the liver and adipose tissue were removed, they were kept frozen until analysis. Lipids from the liver and intra-abdominal fat were extracted by the method described by Folch et al. ${ }^{14}$, and esterified according to the technique described by Hartman and Lago ${ }^{15}$. The fatty acid methyl esters obtained were analyzed by gas chromatography.

The fatty acid profile of the tissues was determined using a Shimadzu GC Model 17A equipped with a fused silica capillary column $(100 \mathrm{~m}$ $x 0.25 \mathrm{~mm}$ ) SP-2560 under the following operating conditions: the carrier gas was hydrogen with a flow rate of $20 \mathrm{~cm} . \mathrm{sec}-1$; initial oven temperature was $140^{\circ} \mathrm{C}$ for $5 \mathrm{~min}$, increased to $240^{\circ} \mathrm{C}$, at $4^{\circ} \mathrm{C} /$ min, and held at $240^{\circ} \mathrm{C}$ for $30 \mathrm{~min}$; injector split ratio was $1 / 50$, temperature $250^{\circ} \mathrm{C}$; vaporization and detector temperatures were $250^{\circ} \mathrm{C}$ and $260^{\circ} \mathrm{C}$, respectively. The fatty acids were identified by comparing them with the retention times of a standard mixture of fatty acids (SIGMA ${ }^{\circledR}$ - ref. 18919).

The SigmaStat software, version 2.03, was used for the statistical analysis using nonparametric 
tests. The Mann-Whitney test was used to compare two independent groups and the Kruskal-Wallis test was used to compare three independent groups, complemented by the Dunn's multiple comparison procedure at $5 \%$ probability. The $p$ value was set at $5 \%(p<0.05)$ to obtain a reliability of $95 \%$.

\section{RES ULT S}

The control group had a higher FER $(p<0.001)$ and consumed more food (Media-M=168.83g, standard deviation-SD=17.40) than the omega-3 group ( $M=134.86 \mathrm{~g}, S D=23.83$ ) (Figure 1).

ACF were observed in both the control and omega-3 groups (Figure 2), but the experimental

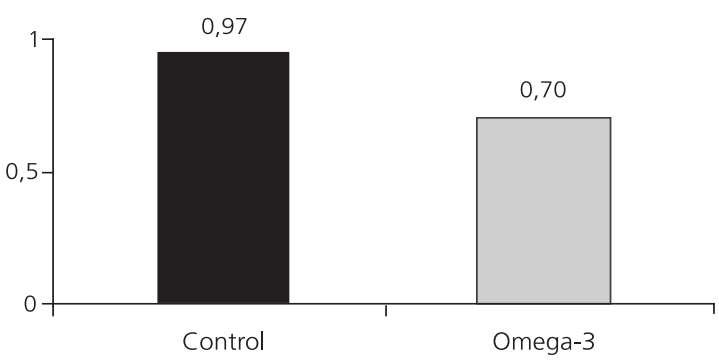

Figure 1. Food intake Efficiency Rate (FER) * $(p<0.001)$, control group $(n=25)$ or omega-3 group $(n=28)$, male Wistar rats for 30-weeks. Universidade Federal de Viçosa (MG), 2003.

group presented a greater number of aberrant crypts than the control group after 15 weeks.

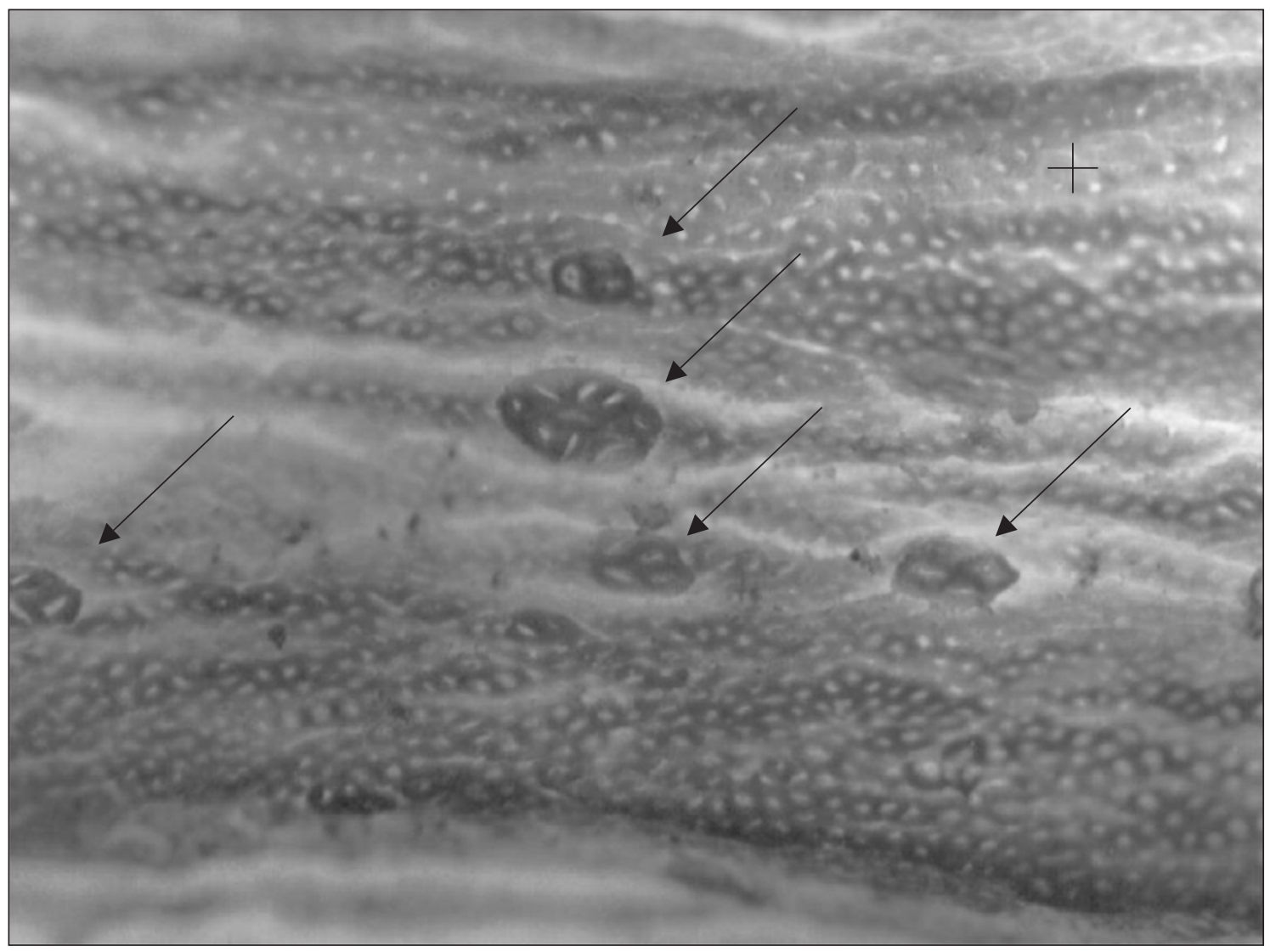

Figure 2. Normal colonic mucosal area (+) and presence of five Aberrant Crypts Foci (ACF). The arrows represent foci with different numbers of aberrant crypts.

The ACF viewing: two of them consisting of three crypts, one consisting of four crypts, one consisting of five and last consisting of nine aberrant crypts located in the center of the figure (40 X)_omega-3 group. Coloured by Methylene blue. 
Figures 3 and 4 show median ACF progress in the two groups. There was a statistical difference in the total number of ACF and the number of $A C F>3$ after 30 weeks. The number of ACF in the omega-3 group dropped $45.71 \%$ and the number of foci with more than three crypts dropped $29.70 \%$ from weeks 13 to 28 . On week 30 , there was $55.34 \%$ less ACF and $57.14 \%$ less $A C F>3$ in the omega-3 group than in the control group.

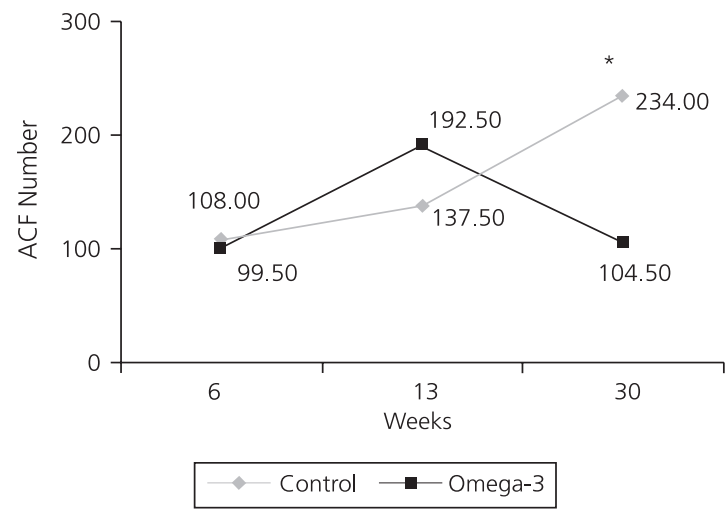

Figure 3. Evolution of Aberrant Crypt Foci (ACF) number, ${ }^{*} \mathrm{p}<0.05$ (median), male Wistar rats for 30-weeks. Universidade Federal de Viçosa (MG), 2003.
The fatty acid profiles, mainly linoleic and arachidonic acid contents of the liver and intraabdominal fat of both groups are shown in Tables 1 and 2. However, EPA and DHA were found only in the liver and visceral fat of the omega 3 group.

In the control group, linoleic acid content dropped while arachidonic acid content rose from week 13 to week 28.

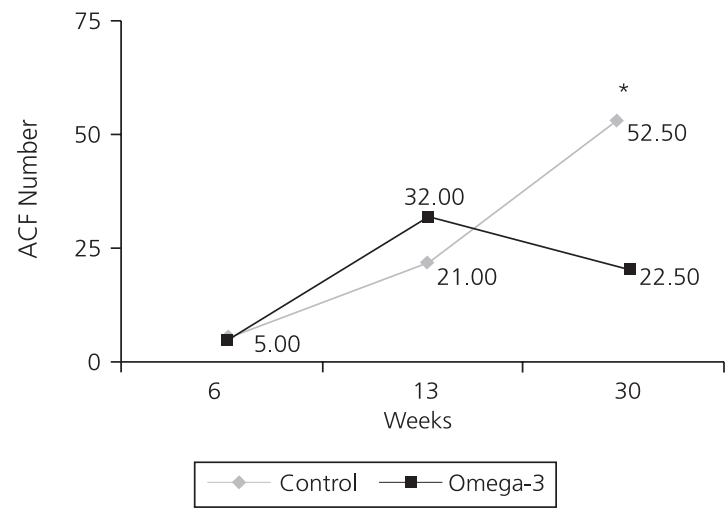

Figure 4. Number of Aberrant Crypt Foci (ACF) with more than 3 crypts (ACF $>3),{ }^{\star} \mathrm{p}<0.05$ (median), male Wistar rats for 30-weeks. Universidade Federal de Viçosa (MG), 2003.

Table 1. Liver and intra-abdominal fatty acid profile (\%) of the control group (median), male Wistar rats during 30-weeks. Universidade Federal de Viçosa (MG), 2003.

\begin{tabular}{|c|c|c|c|c|c|c|}
\hline \multirow{2}{*}{ Weeks } & \multicolumn{3}{|c|}{ Liver } & \multicolumn{3}{|c|}{ Infra-abdominal fat } \\
\hline & 6 & 13 & 28 & 6 & 13 & 28 \\
\hline Linoleic acid & $25.47^{a}$ & $21.58^{a}$ & $20.46^{a}$ & $20.55^{a}$ & $27.37^{a}$ & $39.79^{b}$ \\
\hline Arachidonic acid & $16.68^{\mathrm{ab}}$ & $11.37^{\mathrm{a}}$ & $29.98^{b}$ & & $1.53^{\mathrm{a}}$ & $1.33^{\mathrm{a}}$ \\
\hline
\end{tabular}

Liver Tissue - Kruskal-Wallis $(p<0.05)$. Dunn's: arachidonic acid 13 weeks < 30 weeks; Intra-abdominal fat: Kruskal-Wallis $(p<0.05)$. Dunn's: linoleic acid 13 weeks $<30$ weeks.

Table 2. Liver and intra-abdominal fatty acid profile (\%) of the omega-3 group (median), male Wistar rats during 30-weeks. Universidade Federal de Viçosa (MG), 2003.

\begin{tabular}{|c|c|c|c|c|c|c|}
\hline \multirow{2}{*}{ Weeks } & \multicolumn{3}{|c|}{ Liver } & \multicolumn{3}{|c|}{ Intra-abdominal fat } \\
\hline & 6 & 13 & 28 & 6 & 13 & 28 \\
\hline Linoleic acid & $13.83^{\mathrm{a}}$ & $11.72^{\mathrm{a}}$ & $10.89^{\mathrm{a}}$ & $14.96^{\mathrm{a}}$ & $13.85^{\mathrm{a}}$ & $14.28^{\mathrm{a}}$ \\
\hline Arachidonic acid & $8.27^{\mathrm{a}}$ & $7.04^{\mathrm{a}}$ & $7.07^{\mathrm{a}}$ & & & \\
\hline Eicosapentaenoic acid & $7.69^{\mathrm{a}}$ & $7.69^{a}$ & $9.75^{a}$ & & & 1.61 \\
\hline Docosahexaenoic acid & $28.37^{a}$ & $32.78^{\mathrm{a}}$ & $33.49^{\mathrm{a}}$ & & & 6.55 \\
\hline
\end{tabular}

Liver - Kruskal-Wallis Test $(p<0.05)$. Dunn's: (no significant difference); Intra-abdominal fat: Kruskal-Wallis Test $(p<0.05)$. Dunn's: (no significant difference). 
In the omega-3 group, DHA concentration in weeks 13 and 28 did not differ statistically from that of week 6 .

\section{DISCUSSION}

The control group gained more weight than the omega-3 group during the experiment. The diet supplemented with omega-3 had a higher energetic density than the control diet, so the animals ate less. This is shown by the food intake ratio, measured by FER (Figure 1).

ACF were identified in both groups treated with $\mathrm{DMH}$, proving the efficacy of the carcinogenesis model described by Bird ${ }^{13}$. Different cancer stages or pre-cancer lesion phases (ACF) were found throughout the intervention periods. By week 13 of the dietary intervention, the number of ACF had increased in both groups, without any statistical difference between them. Until week 13, omega-3 had not yet caused a reduction in the number of ACF in the omega-3 group. Good et $a^{1 / 6}$. detected in their study that, after 19 weeks of inducing carcinogenesis with $3 \mathrm{AOM}$ injections $(15 \mathrm{mg} / \mathrm{kg}$ of weight), there were a greater number of ACF in the group treated with fish oil ( $18 \mathrm{~g}$ fish oil/100 $\mathrm{g}$ of diet) than in the group receiving a low concentration of maize oil $(5 \mathrm{~g}$ of maize oil/ $100 \mathrm{~g}$ of diet) $M=586.9, S D=140.5$ vs $M D=486.0$, $S D=89.5$, respectively and in the group receiving a high concentration of maize oil $M D=586.9$, $S D=140.5$ vs $M D=507.6, S D=120.9$, respectively. However, in our study, the dietetic intervention began 12 weeks after carcinogen administration and by then, the mean number of ACF was $\mathrm{MD}=350.1, \mathrm{SD}=61.0$.

The carcinogen used may have different outcomes depending on when it is administered, i.e., during or after dietary intervention. After 30 weeks of dietary intervention, the omega-3 group had less ACF than the control group. Good et al. ${ }^{16}$ found that the number of ACF of the group treated with fish oil 24 weeks after administration of a carcinogen was greater than the number of ACF of the groups treated with low and high concentrations of corn oil. However, in their study, the number of tumors in each group was in the following descending order: group treated with high-fat corn oil, group treated with low-fat corn oil and group treated with high-fat fish oil. It is possible to assume that dysplasia may not occur in various ACF as reported by Bird ${ }^{17}$.

In our study, the number of ACF found in the control group increased significantly from week 6 to week 28. The omega-3 group showed an increase in the number of ACF from week 6 to week 13, but from week 13 to week 28 , the number of ACF decreased statistically. A statistical difference was also found on week 28 between the control and omega-3 groups. There were less ACF with more than 3 aberrant crypts in the control group on week 6 than on week 28, providing further evidence that the number of $A C F>3$ increases over time.

The opposite occurred in the omega-3 group, whose number of $A C F>3$ decreased statistically from week 6 to week 28 . These results may indicate that omega- 3 plays a role in the therapeutic of colon cancer. It is also suggested that as the number of crypts per focus increases, the resistance to apoptosis also increases, resulting in tumor development ${ }^{16,17}$.

Apoptosis is crucial for the regulation of cell numbers and it is one of the mechanisms of mutant cell destruction? ${ }^{7}$. While examining colonic biopsies, Courtiney et al..$^{18}$ found that apoptosis increased significantly in patients with colorectal adenomas after EPA supplementation (2g/day) for 3 months while crypt cell proliferation decreased significantly.

Rodrigues et al. ${ }^{11}$ using four $\mathrm{DMH}$ administrations of $40 \mathrm{mg} / \mathrm{kg}$ of body weight, increased the number of ACF and the number of $A C F>3$. The number of ACF after 4 weeks of dietary intervention went from $\mathrm{MD}=28.4, \mathrm{SD}=8.5$ to $M D=280.4, S D=83.4$. Flax seed oil intake did not have any positive effect in reducing the appearance of ACF.

The effect of omega-3 in preventing or treating colorectal cancer is accomplished by a specific omega-3 fatty acid: DHA ${ }^{19}$. 
Dietary supplementation influenced fatty acid deposition in tissues, as happens with other dietary lipids ${ }^{20}$. The mechanisms of cancer prevention are related with fatty acid absorption and their metabolism to form polyunsaturated fatty acids. They have the ability to modulate the expression of genes involved in the inhibition of tumor growth.

Tissues from the control group had increased AA deposition, probably due to higher amounts of dietary linoleic acid conversion. Omega- 6 derivatives, specifically AA, have proinflammatory effects. The increased number of ACF seen in the control group in week 28 could be due to the eicosanoids produced from AA, i.e., pro-inflammatory agents.

On the other hand, there was high incorporation of pre-formed EPA and DHA from dietary fish oil in the liver of the omega-3 group.

As expected, no stored omega-3 fatty acids were found in weeks 6 and 13 of the experiment, since these fatty acids play a fundamental role in the body as constituents of cell membranes and are frequently used for membrane functions ${ }^{8}$. However, EPA and DHA were found in the visceral adipose tissue of the omega-3 treated group in week 30 . This storage probably occurred because of its high concentration in the diet, reflecting the long-term high level of ingestion.

When comparing this data with the number of $A C F$, it is possible that a higher amount of omega- 3 fatty acids was present in the membranes of colonocytes because the number of ACF is higher in the omega-3 group, especially in week 13. This may have particularly favored the decrease of these ACF seen in week 30 of the dietary intervention. Until then, these acids had not been stored in the intra-abdominal fat (Table 3). According to Teitelbaum \& Walker ${ }^{2}$, high intake of EPA and DHA by humans partially substitutes the omega- 6 fatty acids present in cell membranes. The amount of linoleic acid stored in the intra- abdominal fat of the control group from week 13 onward was statistically higher than that of omega-3 fatty acid.

Despite the lower body weight of the omega-3 group because of less food intake, these animals absorbed enough omega- 3 to effectively reduce the number of ACF. A greater amount of $A A$ was synthesized in the liver of the control group, even though no omega-3 substrate had been supplied for $\Delta 6$-desaturase, resulting in an increased number of ACF in the control group.

Further studies using lower amounts of dietary omega-3 are needed to verify if dietary doses also help decrease the development of preneoplastic lesions during the promotion phase of the disease.

\section{ACKNOWLEDGEMENTS}

This work was sponsored by Fundação de Amparo à Pesquisa de Minas Gerais. JIAL is recieved a fellowship from Conselho Nacional de Desenvolvimento Científico e Tecnológico. Thanks to Jeffrey R. Oar for correcting the English of this text.

\section{COLABORATORS}

V.T. HENRIQUES accomplished the data selection and collection, laboratory analysis, data analysis and interpretation, and manuscript writing. C.M.G.C. DIAS contribute with data interpretation, critical evaluation of the subject and final review of the manuscript. S.C.C. FRANCESCHINI contribute with data interpretation, critical evaluation of the subject and final review of the manuscript. C.M. SBARENSE standardization of protocol of lipids analysis and Contribute final review of the manuscript. N.M.B. COSTA and J.I.A. LEITE critical evaluation of the subject and final review of the manuscript. M.C.G. PELUZIO was responsible for coordinating the project which originates this paper, accomplished selection and collection of data statistical analysis and interpretation, critical evaluation of the subject and final review of the manuscript. 


\section{REFERENCES}

1. Waitzberg $D L$, editor. Nutrição oral, enteral e parenteral na prática clínica. São Paulo: Atheneu; 2000.

2. Teitelbaum JA, Allan Walker W. Review: the role of omega 3 fatty acids in intestinal inflammation. J Nutr Biochem. 2001; 12(1):21-32.

3. Tapiero H, Ba GN, Couvreur P, Tew KD. Polyunsaturated fatty acids (PUFA) and eicosanoids in human health and pathologies. Biomed Pharmacother. 2002; 56(5):215-22.

4. Calder PC. Polyunsaturated fatty acids and inflammation. Prostaglandins Leukot Essent Fatty Acids. 2006; 75(3):197-202.

5. Chapkin RS, McMurray DN, Lupton JR. Colon cancer, fatty acids and anti-inflammatory compounds. Curr Opin Gastroenterol. 2007; 23(1):48-54.

6. Esteve J, Kricker A, Parkin DM, editors. Facts and figures of colon cancer in the European community. Lyon: International Agency for Research on Câncer; 1993.

7. Llor X, Pons E, Roca A, Alvarez M, Mañé J, Fernández-Bañares $F$, et al. The effects of fish oil, olive oil, oleic acid and linoleic acid on colorectal neoplastic processes. Clin Nutr. 2003; 22(1):71-9.

8. Roynette CE, Calder PC, Dupertuis YM, Pichard C. n-3 Polyunsaturated fatty acids and colon cancer prevention. Clin Nutr. 2004; 23(2):139-51.

9. Reddy BS. Omega-3 fatty acids in colorectal cancer prevention. Int J Cancer. 2004; 112(1):1-7.

10. Larsson SC, Kumlin M, Ingelman-Sundberg $M$, Wolk A. Dietary long chain n-3 fatty acids for the prevention of cancer: a review of potential mechanisms. Am J Clin Nutr. 2004; 79(6):935-45.

11. Rodrigues MAM, Silva LAG, Salvadori DMF, De Camargo JLV, Montenegro MR. Aberrant crypt foci and colon cancer: comparison between a short-and medium-term bioassay for colon carcinogenesis using dimethylhydrazine in Wistar rats. Braz J Med Biol Res. 2002; 35(3):351-5.

12. Reeves PG, Nielsen FH, Fahey GC Jr. AIN-93 Purified diets of laboratory rodents final report of the American Institute Nutrition ad hoc writing committee on there formulation of the AIN-76A rodent diet. J Nutr. 1993; 123(11):1939-51.

13. Bird RP. Observations and quantification of aberrant crypts in the murine colon treated with a colon carcinogen: preliminary findings. Cancer Letter.1987; 37(2):147-51.

14. Folch J, Lees M, Sloane SG. A simple method for the isolation and purification of total lipids from animal tissues. J Biol Chem. 1957; 226(1):497-509.

15. Hartman L, Lago RC. Rapid preparation of fatty acid methyl esters from lipids. Lab Pratic. 1973; 22(6):475-6.

16. Good CK, Lasko CM, Adam J, Bird PR. Diverse effects of fish oil on the growth of aberrant crypt foci and tumor multiplicity in F344 rats. Nutr Cancer. 1998; 31(3):204-11.

17. Bird RP. Role of aberrant crypt foci in understanding the pathogenesis of colon cancer. Cancer Lett. 1995; 93 (1):55-71.

18. Courtiney ED, Matthews S, Finlayson C, Di Pierro $D$, Belluzzi A, Roda E, et al. Eicosapentaenoic acid (EPA) reduces crypt cell proliferation and increases apoptosis in normal colonic mucosa in subjects with a history of colorectal adenomas. Int J Colorectal Dis. 2007; 22(7):775-6.

19. Chapkina RS. Mechanisms by which docosahexaenoic acid and related fatty acids reduce colon cancer risk and inflammatory disorders of the intestine. Chem Phys Lipids. 2008; 153(1):14-23.

20. Roynettea CE, Calderb PC, Dupertuisa, YM, Pichard C. n-3 Polyunsaturated fatty acids and colon cancer prevention. Clin Nutr. 2004; 23(2):139-51.

Received on: $5 / 6 / 2007$

Final version resubmitted on: 4/7/2008 Approved on: 8/10/2008 